\title{
The effect of debt, firm size and liquidity on investment -cash flow sensitivity
}

\author{
Hechmi Soumaya \\ The Faculty of the Economic sciences and Management of Nabeul, Tunisia \\ E-mail: b04_soumaya@yahoo.fr \\ Tel : (216) 97194506
}

Received: July 05, 2012 Accepted: August 07, 2012 DOI: 10.5296/ijafr.v2i2.2064

\begin{abstract}
Given the importance of cash flow, being in determining the investment performance of firms, we have presented an overview of purely practical studies that analyze this relationship. The majority of these studies have proven the existence of such relationship, both significant and positive, between investment and the $\mathrm{CF}$, but the unanimity has not explained this positive relationship.

We are interested only in analyzing the effect of the debt, liquidity and firm size on the investment-cash flow sensitivity on a sample of 82 French firms that compose the SBF 250 index, from 1999 to 2005 . Thus, we have noticed that the debt has a negative effect on the investment-cash flow sensitivity and the firm size has a positive effect on this relationship.
\end{abstract}

Keywords: investment-cash flow sensitivity, debt, liquidity and firm size 


\section{Mll Macrothink}

International Journal of Accounting and Financial Reporting

ISSN 2162-3082

2012, Vol. 2, No. 2

The growth depends double on the investment. Indeed, the investment is, in the side of the consumption, one of the important components of the demand. A decrease of the investment is translated by a slowing down of growth. But it also plays a determining role to model the productive capacity of an economy.

This very strong link between investment and growth incites to analyze the determinants of the investment, to understand better which strategy of economic policy would may support a well-balanced progress of the investment.

\section{1- Theoretical Framework:}

\section{A- The effect of debt:}

The hypothesis of perfected capital markets on which base themselves the empirical models of investment supposes that, in a world without tax nor transactions costs, the value of a firm and the profitability of an investment are independent from the mode of financing, that it is made by debts ( external sources) or by equity capital (internal sources). But the existence of imperfections in financial markets, including the problems of asymmetric information between lenders (credit institutions) and borrowers (firms), can generate frictions that make the investment decisions dependent from the chosen mode of financing. Consideration of these information asymmetries in the modeling of the market of credit has led to two types of results that complement each other, with a direct impact on the investment behavior of firms. First, among the conclusions concerning the models incorporating of information asymmetries is that the cost of external financing of such firm depends on its financial situation. Second, other models conclude that, under certain circumstances, the existence of incomplete information on the quality of investment projects of firms leads the lenders to adjust interest rates according to the particular situation of each firm.

If the firm cannot satisfy any requirements that are imposed by the markets of external financing, it will realize the only investments that are compatibles with its internal financing (which depends on the rate of current profit and the rate of anticipated profit), investments that can be inferior to what would have been advisable to maintain or develop its competitive position. Thus, the firm risks to be failing by default to invest (due to the rationing of external financing and the lack of internal financing given to the desirable investments).

In other words, a firm has, first, to invest with its appropriate resources. If these are insufficient, the firm must borrow. If its size allows it, it can also, raise the capitals ${ }^{1}$. The Financing conditions of such productive investment depend on characteristics of the financial situation of each firm.

Even, if the debt offers a certain advantage by playing a role of leverage ratio, it could push the firm to an exaggerated debt policy. Indeed, an increased volume of debt implies autonomy of management and discourages eventual providers of capitals.

The capacity of a firm to borrow depends on many guarantees that can offer, and on the conditions of market (level of interest rates). The level of profits and the level of debt of the

1- Kergueris, J, (2002), “Les determinants de l'investissement”, Rapport d'information du Sénat N³5 (2002-2003), www.senat.fr 


\section{Al Macrothink}

International Journal of Accounting and Financial Reporting

ISSN 2162-3082

2012, Vol. 2, No. 2

firm are the two main indicators to estimate the abilities to repay borrower. In this way, the investment is determined by the level of profits and debt.

Debt is used as an indicator of the financial solidity of the firm and can condition the cost of external resources or the access to these resources.

The table below summarizes the results of researches that studied the relationship between investment and debt:

\section{Table 1: Studies on the effect of debt on the investment}

\begin{tabular}{|c|c|c|c|}
\hline Author & Year & Subjet of study & Results of study \\
\hline $\begin{array}{l}\text { Deveureux } \\
\text { and } \\
\text { Schiantarelli }^{2}\end{array}$ & 1989 & $\begin{array}{l}\text { Study the impact of } \\
\text { financial factors as } \\
\text { the } \mathrm{CF} \text {, the debts } \\
\text { and the measures of } \\
\text { liquidity stock on } \\
\text { the investment } \\
\text { decisions. }\end{array}$ & $\begin{array}{l}\text { - The authors notice that the internal } \\
\text { sources are similar to the external } \\
\text { sources of financing; } \\
\text { - The long-term debts represent a low } \\
\text { rate of the investment financing } \\
\text { especially to the small firms because, it } \\
\text { is expensive, for them to count on the } \\
\text { markets of debts. }\end{array}$ \\
\hline $\begin{array}{l}\text { Galeotti and } \\
\mathrm{al}^{3}\end{array}$ & 1994 & $\begin{array}{l}\text { - Study the } \\
\text { consequences of } \\
\text { the imperfect } \\
\text { substitutability } \\
\text { between internal } \\
\text { and external } \\
\text { sources } \\
\text { financing for the } \\
\text { real decisions of } \\
\text { firms; } \\
\text { - Analyze the } \\
\text { relationship } \\
\text { between } \\
\text { financial variables } \\
\text { and the investment } \\
\text { in case of imperfect } \\
\text { capital markets. } \\
\Rightarrow \text { The to } \\
\text { authors have used } \\
\text { two sources to } \\
\text { collect }\end{array}$ & $\begin{array}{l}\text { - For those firms whose data } \\
\text { are collected from the first source, they } \\
\text { support the costs of agency and } \\
\text { financial distress, which increases the } \\
\text { ratio Debts / Equity. This may reflects } \\
\text { the importance of the debt in their } \\
\text { financial structure; } \\
\text { - For the other firms, the change of } \\
\text { debts doesn't play an important role. } \\
\text { This may reflect the fact that these firms } \\
\text { tend to finance their investment beyond } \\
\text { the undelivered profits and to have a } \\
\text { low ratio Debt / Equity. }\end{array}$ \\
\hline
\end{tabular}

2- Devereux.M and Schiantarelli.F (1989), « Investment, financial factors and cash flow : Evidence from UK panel data », www.nber.org

3- Galeotti, M., Schiantarelli, F. and Jaranillo, F, (1994), « Investment decisions and the role of debt, liquid assets and cash-flow : Evidence from Italian panel data », Applied Financial Economics, 4 


\begin{tabular}{|c|c|c|c|}
\hline Author & Year & Subjet of study & Results of study \\
\hline & & in their sample. & \\
\hline $\begin{array}{l}\text { Estrada and } \\
\text { Valles }{ }^{4}\end{array}$ & 1998 & $\begin{array}{l}\text { - Test the influence } \\
\text { of financial } \\
\text { variables on the } \\
\text { investment } \\
\text { decisions within the } \\
\text { limits of the } \\
\text { classical framework } \\
\text { in which all the } \\
\text { firms handle the } \\
\text { same marginal cost } \\
\text { of debt (Spanish } \\
\text { industrial firms) }\end{array}$ & $\begin{array}{l}\text {-The demand of Investment is } \\
\text { statistically acceptable and the } \\
\text { additional cost of external sources is an } \\
\text { average of } 0.4 \% \text {. These results } \\
\text { confirm the existence of asymmetric } \\
\text { information in credit markets, what } \\
\text { implies a premium in the cost of } \\
\text { external financing which depends on } \\
\text { both characteristics of the firm: the } \\
\text { debt and the guarantee. }\end{array}$ \\
\hline $\begin{array}{l}\text { Miguel and } \\
\text { Pindado }^{5}\end{array}$ & 2001 & $\begin{array}{l}\text { - Analyze the } \\
\text { characteristics of } \\
\text { the firm that are } \\
\text { considered as the } \\
\text { determinants of the } \\
\text { capital structure } \\
\text { according } \\
\text { different } \\
\text { explanatory } \\
\text { theories, } \\
\text { - How do the } \\
\text { institutional } \\
\text { characteristics } \\
\text { affect the capital } \\
\text { structure? }\end{array}$ & $\begin{array}{l}\text { - For the non-financial firms, they } \\
\text { support costs of transaction when they } \\
\text { decide to adjust their level of debt, } \\
\text { - An opposite relationship between the } \\
\text { costs of financial straits and debt, } \\
\text { caused by the high premium demanded } \\
\text { by the creditors, } \\
\text { - A direct relationship between debt and } \\
\text { investment, thus, confirms the } \\
\text { simultaneity of the two decisions } \\
\text { (investment and financing). }\end{array}$ \\
\hline $\begin{array}{l}\text { Artola and } \\
\mathrm{al}^{6}\end{array}$ & 2002 & $\begin{array}{l}\text { Study the } \\
\text { determinants of } \\
\text { investment } \\
\text { behavior of French }\end{array}$ & $\begin{array}{l}\text { The result suggests that the investment } \\
\text { behavior of firms in the forced regime } \\
\text { (without dividend payment) shows a } \\
\text { strong sensitivity to the generation of }\end{array}$ \\
\hline
\end{tabular}

4- Estrada, A. and Valles, J, (1998), «Investment and financial structure in Spanish manufacturing firms », Investigaciones Economicas, vol.XXII (3)

5- Miguel, A. and Pindado, J, (2001), « Determinants of capital structure : new evidence from Spanish panel data », Journal of Corporate Finance, 7

6- Artola, C. and Al, (2002), «Investissement et contraintes financières en France et en Espagne : Etude économétrique sur données d'entreprises manufacturières », Bulletin de la Banque de France, N106 


\begin{tabular}{|c|c|c|c|}
\hline Author & Year & Subjet of study & Results of study \\
\hline & & $\begin{array}{l}\text { and Spanish } \\
\text { industrial firms. }\end{array}$ & internal sources. \\
\hline $\begin{array}{l}\text { Nam and } \\
\text { Radulescu }^{7}\end{array}$ & 2004 & $\begin{array}{l}\text {-Check out the } \\
\text { existence of such } \\
\text { maturity of debt for } \\
\text { the investment } \\
\text { decisions, } \\
\text { - Study the } \\
\text { sensitivity of } \\
\text { maturity optimum } \\
\text { to the change of the } \\
\text { tax, the interest rate } \\
\text { and the inflation on } \\
\text { the firms. }\end{array}$ & $\begin{array}{l}\text { - The existence of a maturity optimum } \\
\mathrm{S} * \text { in which the NPV (real and } \\
\text { nominal) reaches a maximum, } \\
\text { - The maturity optimum of debt is } \\
\text { positively correlated with the corporate } \\
\text { tax and the inflation rate, but it is } \\
\text { negatively related to the interest rate. }\end{array}$ \\
\hline Hennessy $^{8}$ & 2004 & $\begin{array}{l}\text { This study removes } \\
\text { an empirical proxy } \\
\text { for the marginal Q } \\
\text { lever of equity, } \\
\text { producing a direct } \\
\text { test for the debt and } \\
\text { the reduction of the } \\
\text { impact through the } \\
\text { establishment of an } \\
\text { additional and fixed } \\
\text { debt. }\end{array}$ & $\begin{array}{l}\text { The negative effect of the debt on the } \\
\text { investment is stronger than it is going to } \\
\text { be implied by the canal of the debt } \\
\text { working remotely. }\end{array}$ \\
\hline Savignac $^{9}$ & 2006 & $\begin{array}{l}\text { - Study the impact } \\
\text { of the financial } \\
\text { constraints on the } \\
\text { innovation behavior } \\
\text { of firms. . }\end{array}$ & $\begin{array}{l}\text {-Negative effect of the rate of banking } \\
\text { debts on the probability to undertake an } \\
\text { innovative project. }\end{array}$ \\
\hline
\end{tabular}

In the end, the companies are interested in running into debt in order to profit from the leverage, and from the fiscal benefit related to the debt (the interests are deductible from the corporate tax). But the growth of debt pulls a greater failure risk. The firm has to arbitrate between the benefits linked to the debt and the cost of failure risk.

7- Nam, C.W. nd Radulescu, D.M, (2004), « Does debt maturity matter for investment decisions”, www.ssrn.com 8- Hennessy, C.A, (2004), « Tobin's Q, debt overhang and investment », The Journal of Finance, vol.LIX, N4

9- Savignac, F, (2006), « The impact of financial constraints on innovation : Evidence from French manufacturing firms », www.google.com.

10- Connolly, R.A and Hirschey,M (2005), « Firm size and the effect of R\&D on Tobin's q », R\&D Mangement, 35,2. 


\section{B-The effect of firm size:}

The role of firm size is considered as an important theme in the literature of the innovative activity. Since the last works of Schumpeter, we have become aware of the role of firm size in the creation of knowledge. As Schumpeter ${ }^{10}$ believes that the large firms have the opportunity to be the most important source of innovation, the American experience through the past decade suggests a role rarely important of small firms. The technological development, the progress in biotechnology and the change in the nature of drug discovery clearly show that small firms cannot be an obstacle to reach the market value of innovation.

The firm size has attracted the attention of many researchers in other fields, too. Concerning the financial economics, the sophisticated models are still unable to explain the stock returns, which are exceptionally high for small firms, and this remains a sustainable perplexity. Evaluate the small firms has proved to be a very difficult task. This is why the small firms benefit of an important attention in most economics. The existence of constraints in the investment activity caused by the obstacles to the access of the external capital markets raises political aspects, especially if these constraints are more important for small firms. Therefore, the impact of the firm size on the investment constraints remains a matter of special interest.

The small firms are typically followed by analysts who have to prove the high degree of information asymmetry between the internals of the firm and its externals. The small firms also face high transaction costs. If these effects are economically significant, it is expected that small firms use more internal sources. The agency costs may be higher for small firms. All these factors raise the costs of using external sources on small firms.

In addition, the firm size plays also a role in other fields. In order to check these findings, we have checked the effect of the firm size on the investment through several studies that were conducted on that subject. So, the results are summarized in the following table:

Table 2: The studies on the size effect on the investment

\begin{tabular}{|l|l|l|l|}
\hline Author & Year & Subject of study & Results of study \\
\hline $\begin{array}{l}\text { Deveureux } \\
\text { and } \\
\text { Schiantarelli }\end{array}$ & 1989 & $\begin{array}{l}\text { Impact of firm size on the } \\
\text { Cash Flow- } \\
\text { Investment sensitivity } \\
\Rightarrow \text { Criterion of segmentation: } \\
\text { the real value of capital stock } \\
\text { (English Firms) }\end{array}$ & $\begin{array}{l}\text { The Investment-cash flow sensitivity } \\
\text { decreases with the size, because the } \\
\text { small firms generate a CF equal to } \\
18 \% \text { while the big firms generate } \\
11 \% \text { only. }\end{array}$ \\
\hline $\begin{array}{l}\text { Oliner and } \\
\text { Rudebusch }\end{array}$ & $\begin{array}{l}\text { Study of the Investment-cash } \\
\text { flow sensitivity. }\end{array}$ & $\begin{array}{l}\text { The effect of the size is not } \\
\text { significant. They argue that this result } \\
\text { is due to the nature of their sample }\end{array}$ \\
\hline
\end{tabular}

11- Devereux.M and Schiantarelli.F (1989), «Investment, financial factors and cash flow : Evidence from UK panel data », www.nber.org

12- Kadapakkam, P.R., Kumar, P.C. and Riddick, L.A, (1998), “The impact of cash flows and firm size on investment: The 


\begin{tabular}{|c|c|c|c|}
\hline Author & Year & Subject of study & Results of study \\
\hline & 1992 & & $\begin{array}{l}\text { that includes } 120 \text { companies among } \\
500 \text { Fortune. Therefore, their sample } \\
\text { may not reflect a significant } \\
\text { difference in the firm size. }\end{array}$ \\
\hline $\operatorname{Vogt}^{12}$ & 1994 & $\begin{array}{l}\text { Impact of the firm size on the } \\
\text { Investment-cash flow } \\
\text { sensitivity } \\
\Rightarrow \text { Criterion of segmentation } \\
\text { based on the book value of } \\
\text { the firm (American Firms). }\end{array}$ & $\begin{array}{l}\text { The Cash Flow Investment } \\
\text { sensitivity is greater for the } \\
\text { companies belonging to the highest } \\
\text { quintile in comparison to the lowest } \\
\text { quintile }\end{array}$ \\
\hline $\begin{array}{l}\text { Athey and } \\
\text { Laumans }^{12}\end{array}$ & 1994 & $\begin{array}{l}\text { Impact of the firm size on } \\
\text { the Investment-cash flow } \\
\text { sensitivity } \\
\Rightarrow \quad \text { Criterion of } \\
\text { segmentation: book value of } \\
\text { equity (Indian Firms) }\end{array}$ & $\begin{array}{l}\text { The Investment-cash flow sensitivity } \\
\text { is higher for large firms. }\end{array}$ \\
\hline $\begin{array}{l}\text { Cohen and } \\
\text { Klepper }^{13}\end{array}$ & 1996 & $\begin{array}{l}\text { The relationship between the } \\
\text { investment in } R \& D \text { and } \\
\text { the firm size. }\end{array}$ & $\begin{array}{l}\text { - The probability of undertaking } \\
\text { investments in R \& D increases with } \\
\text { the size of the firm; } \\
\text { - The Investments in R \& D and the } \\
\text { firm size are closely and positively } \\
\text { related; } \\
\text { - The Investments in R \& D increase } \\
\text { proportionally with the firm size in } \\
\text { most industries.. }\end{array}$ \\
\hline $\begin{array}{l}\text { Ghosal and } \\
\text { Loungani }^{14}\end{array}$ & 1996 & $\begin{array}{l}\text { The role of the firm size in } \\
\text { studying the effect of the } \\
\text { uncertainty on the } \\
\text { investment. }\end{array}$ & $\begin{array}{l}\text { In the industries dominated by small } \\
\text { firms, the increased uncertainty } \\
\text { concerning the future profits } \\
\text { decreases the investment. But in all } \\
\text { other industries, the increased } \\
\text { uncertainty hasn't any effect (or has a } \\
\text { positive effect) on the investment. }\end{array}$ \\
\hline & & $\begin{array}{l}\text { Impact of the size on the } \\
\text { Investment-cash }\end{array}$ & $\begin{array}{l}\text { The investment-cash flow } \\
\text { Sensitivity is higher in the group of }\end{array}$ \\
\hline
\end{tabular}




\begin{tabular}{|c|c|c|c|}
\hline Author & Year & Subject of study & Results of study \\
\hline $\begin{array}{l}\text { Kadapakkam } \\
\text { and } \mathrm{al}^{15}\end{array}$ & 1998 & $\begin{array}{l}\text { sensitivity } \\
\text { 3criteria of segmentation: } \\
\text { - Market value of the firm; } \\
\text { - Value of total assets; } \\
\text { - Value of sales } \\
\text { (Turnover). } \\
\text { (Canada, France, Germany, } \\
\text { Great Britain, Japan and } \\
\text { USA). }\end{array}$ & $\begin{array}{l}\text { large firms and it is lower in the } \\
\text { group of small firms and it } \\
\text { independently of the chosen size } \\
\text { measure. } \\
\text { The authors explain that either by the } \\
\text { fact that large companies have much } \\
\text { flexibility in the timing of their } \\
\text { investment or by the fact that they are } \\
\text { more sensitive to agency problems. }\end{array}$ \\
\hline $\begin{array}{l}\text { Fishman and } \\
\operatorname{Rob}^{16}\end{array}$ & 1999 & $\begin{array}{l}\text { Relationship between the } \\
\text { firm size and the investment } \\
\text { in R \& D. }\end{array}$ & $\begin{array}{l}\text { The big firms realize higher profits, } \\
\text { they invest more in R \& D (because, } \\
\text { for them, the effect of cost reduction } \\
\text { is applied for a bigger base of } \\
\text { customers, which is more profitable) } \\
\text { and they offer (on average) lower } \\
\text { prices. }\end{array}$ \\
\hline $\begin{array}{l}\text { Connolly and } \\
\text { Hirschey }^{17}\end{array}$ & 2005 & $\begin{array}{l}\text { Impact of the size on the } \\
\text { effect of } \mathrm{R} \& \mathrm{D} \text { expenses on } \\
\text { the firm value. } \\
\text { Criterion of Segmentation: } \\
\text { market capitalisation. }\end{array}$ & $\begin{array}{l}\text { The effect of the intensity of } \mathrm{R} \& \mathrm{D} \\
\text { on market value is positively linked } \\
\text { to the firm size. }\end{array}$ \\
\hline $\begin{array}{l}\text { Fagiolo and } \\
\text { Luzzi }^{18}\end{array}$ & 2006 & $\begin{array}{l}\text { Relationship between the } \\
\text { liquidity constraints and the } \\
\text { firm size. } \\
\text { Criterion of Segmentation: } \\
\text { number } \\
\text { employees. (Italian Industrial } \\
\text { Firms) }\end{array}$ & $\begin{array}{l}\text { The liquidity constraints have a } \\
\text { negative effect on the growth, } \\
\text { depending on the size. The small } \\
\text { firms are growing more after } \\
\text { controlling the liquidity constraints. } \\
\text { The negative effect of the size on the } \\
\text { growth increases when the liquidity } \\
\text { constraints become more difficult. } \\
\Rightarrow \text { more the liquidity constraints } \\
\text { increase more the negative effect of } \\
\text { the size on the growth increases. }\end{array}$ \\
\hline
\end{tabular}

15- Kadapakkam, P.R., Kumar, P.C. and Riddick, L.A, (1998), "The impact of cash flows and firm size on investment: The international evidence", Journal of Banking and Finance, vol.22

16- Fishman, A. and Rob, R, (1999), « The size of firms and R\&D investment », International Economic Review, vol.40, $\mathrm{N}^{\circ} 4$.

17- Connolly, R.A and Hirschey,M (2005), «Firm size and the effect of R\&D on Tobin's q », R\&D Management, 35,2.

18- Fagiolo, G. and Luzzi, A, (2006), « Do liquidity constraints matter in explaining firm size and growth ? Some evidence from the Italian manufacturing industry”, Industrial and Corporate Change, vol.15, $\mathrm{N}^{\circ} 1$. 


\begin{tabular}{|l|l|l|l|}
\hline Author & Year & Subject of study & Results of study \\
\hline Savignac $^{19}$ & 2006 & $\begin{array}{l}\text { The size as factor affecting } \\
\text { the propensity of firms to } \\
\text { innovate. } \\
\text { (French Industrial Firms) }\end{array}$ & $\begin{array}{l}\text { The probability to be confronted with } \\
\text { constraints for the innovation } \\
\text { decreases with the size of the firm. In } \\
\text { addition, it is easy to finance an } \\
\text { innovative project in the big firms } \\
\text { which have the knowledge and can } \\
\text { maintain better relationships with } \\
\text { potential providers of capital. }\end{array}$ \\
\hline
\end{tabular}

\section{Methodology:}

The objective of our research is to study the effect of the debt, the size and the liquidity on the investment-cash flow sensitivity.

To achieve this goal, we will use the following linear regression:

$$
\mathrm{I}_{\mathrm{it}}=\mathrm{a}_{0}+\mathrm{a}_{1} \mathrm{CF}_{\mathrm{it}}+\mathrm{a}_{2} \mathrm{DLMT}_{\mathrm{it}}+\varepsilon_{\mathrm{it}}
$$

$$
\begin{aligned}
& \text { or } \mathrm{a}_{2} \mathrm{SIZE}_{\mathrm{it}}+\varepsilon_{\mathrm{it}} \\
& \text { or } \quad \mathrm{a}_{2} \mathrm{CS}_{\mathrm{it}-1}+\mathrm{a}_{3} \mathrm{LA}_{\mathrm{it}-1}+\varepsilon_{\mathrm{it}}
\end{aligned}
$$

With ;

$\mathrm{I}_{\mathrm{it}}$ : the investment of the firm i during the year $\mathrm{t}$,

$$
\mathrm{I}_{\mathrm{it}}=\Delta \mathrm{FA}+\mathrm{DA}_{\mathrm{it}}
$$

$\Delta \mathrm{FA}:$ The variation of fixed assets $=\mathrm{FA}_{\mathrm{it}}-\mathrm{FA}_{\mathrm{it}-1}$.

$\mathrm{DA}_{\mathrm{it}}$ : depreciations and amortisations of the firm i during the year $\mathrm{t}$.

These two variables are collected from financial statements.

The $\mathrm{I}_{\mathrm{it}}$ is the dependent variable. For the independent variables, they are among five.

* CF: The cash flow which is calculated by adding to the net profit depreciations and amortisations $\left(\mathrm{CF}_{\mathrm{it}}=\mathrm{NP}_{\mathrm{it}}+\mathrm{DA}_{\mathrm{it}}\right)$.

* DLMT: The long and medium-term debts which are calculated from financial statements.

* CS: The cash stock. It is calculated as the sum of cash and marketable securities $\left(\mathrm{CS}_{\mathrm{it}-1}=\right.$ cash $_{\text {it-1 }}+$ marketable securities $\left._{\text {it-1 }}\right)$.

* LA: The liquid assets which corresponding to the working capital.

Working Capital $_{\text {it-1 }}=$ Invested Capital $_{\text {it-1 }}-$ Fixed Assets $_{\text {it-1 }}$

With;

Invested Capital $=$ equity + long and medium-term debts.

* SIZE: The size of the firm measured by its Market Capitalisation (MC).

Market capitalisation $_{i t}=$ Number of outstanding shares $*$ Share Price $_{i t}$.

19- Savignac, F, (2006), « The impact of financial constraints on innovation : Evidence from French manufactoring firms », www.google.com. 


\section{Al Macrothink}

International Journal of Accounting and Financial Reporting ISSN 2162-3082 2012, Vol. 2, No. 2

All the variables are going to be returned to the scale by dividing them by the total of assets of the period.

The sample of our study is constituted by all the companies quoted in the Paris Stock Exchange and composing the SBF250 index and which are introduced before 1999 (companies introduced in 2000 and later are not included in our sample). For lack of unavailability of the data, the definitive sample consists of 82 companies.

The period of study spreads out over 7 years: from 1999 to 2005 .

\section{Results and Interpretations:}

\section{1- The effect of debt:}

The following table will summarize these results:

Table 3: Linear regression of the effect of debt on the Cash Flow Investment sensitivity

\begin{tabular}{|l|l|l|l|}
\hline VARIABLES & COEFFICIENTS & $\begin{array}{l}\text { T for } \\
\text { Ho :Parameter = }\end{array}$ & Prob $>|\mathbf{T}|$ \\
\hline Constant & $\begin{array}{l}14.24144 \\
(0.649749)\end{array}$ & $21.91839^{*}$ & 0.0000 \\
\hline CF & $\begin{array}{l}-0.227991 \\
(0.031008)\end{array}$ & $-7.352688^{*}$ & 0.0000 \\
\hline DLMT & $\begin{array}{l}-1.808823 \\
(0.055621)\end{array}$ & $-32.52058^{*}$ & 0.0000 \\
\hline DW & 2.902 & - & - \\
\hline$R^{2}$ & $88.05 \%$ & - & - \\
$R^{2}$ adjusted & $86.02 \%$ & - & - \\
\hline
\end{tabular}

* Significant at the $1 \%$ level.

The values between parentheses are the standard errors.

The quality of the model is confirmed by an adjusted R2 to $86.02 \%$.

We notice that the DLMT have a negative effect on the cash flow Investment sensitivity.

If the debt increases, it will have a negative effect on the relationship between investment and the cash flow. This result is similar to what we have already found in the first section. The pecking order theory (POT) states that there is an order of adoption of financing sources: internal financing, long-term debt and finally capital increase.

The internal financing is the process which consists to finance the needs with the resources taken from the activity of the firm. Thus, it avoids the use of external funding. There are two reasons that underlie this choice. On one hand, the risk of the firm does not increase contrary to the debt. On the other hand, we avoid creating conflicts of interests between shareholders and creditors. Beside, contrary to the capital increase, the internal financing is not 


\section{Al Macrothink}

International Journal of Accounting and Financial Reporting

ISSN 2162-3082

2012, Vol. 2, No. 2

accompanied by a dilution effect. It has, finally, the advantage of avoiding the firm to disclose information to investors in case of external financing.

The French companies quoted in the Paris Stock Exchange seem to prioritize their funding resources contrary to the POT, they neither privilege the internal financing nor the debt of the investment financing. The validation of the Pecking Order Theory relies on the existence of asymmetric information which may lead to many adverse selection problems from external investors. The role of informational asymmetries on the financing choice of French companies is not confirmed.

\section{2 - The effect of the firm size:}

The following table will summarize these results:

Table 4: Linear regression of the effect of the size on the Cash Flow Investment sensitivity

\begin{tabular}{|l|l|l|l|}
\hline VARIABLES & COEFFICIENTS & $\begin{array}{l}\text { Tr for } \\
\text { Ho :Parameter } \\
\mathbf{0}\end{array}$ & Prob $>|\mathbf{T}|$ \\
\hline Constant & $\begin{array}{l}1.599876 \\
(0.774177)\end{array}$ & $2.066551^{* *}$ & 0.0393 \\
\hline $\mathrm{CF}$ & $\begin{array}{l}-0.089915 \\
(0.039752)\end{array}$ & $-2.261894^{* *}$ & 0.0241 \\
\hline $\mathrm{MC}$ & $\begin{array}{l}0.261506 \\
(0.013055)\end{array}$ & $20.03126^{*}$ & 0.0000 \\
\hline $\mathrm{DW}$ & 3.105 & - & - \\
\hline $\mathrm{R}^{2}$ & $79.24 \%$ & - & - \\
\hline $\mathrm{R}^{2}$ adjusted & $75.73 \%$ & - & - \\
\hline
\end{tabular}

* Significant at the $1 \%$ level, ** significant at the $5 \%$ level.

The values between parentheses are the standard errors.

We notice that the coefficients of both variables (CF and MC) are significant. As a result, we can say that the size has a positive effect on the investment-cash flow sensitivity.

In the French companies, more the size increases, more the investment will be sensitive to variations of cash flow. For a large firm, if the cash flow increases, the investment decreases.

There are several researches that have studied the impact of the firm size on the investment-cash flow sensitivity. The common point is the significance of this effect but what differs is its sign (positive or negative).

Deveureux and Schiantarelli (1989) ${ }^{20}$ concluded in their studies ,that the cash

20- Devereux.M and Schiantarelli.F (1989), «Investment, financial factors and cash flow : Evidence from UK panel data », 


\section{Macrothink}

International Journal of Accounting and Financial Reporting

ISSN 2162-3082

2012, Vol. 2, No. 2

flow- investment sensitivity decreases with the size, since the small firms generate a CF equal to $18 \%$ while the large firms generate only $11 \%$.

While Athey and Laumans (1994) and Kadapakkam and al (1998) ${ }^{21}$ noticed that the investment-cash flow sensitivity is higher in the group of large firms and it is lower in the group of small firms independently of the size chosen measure.

Kadapakkam and al (1998) explained this result. First, large companies have much flexibility in choosing the time to invest and may delay the investments until internal sources would be available. Competitive pressures may be more intense for the small companies, which may face the situation of 'do or die '. So, small companies may be forced to undertake investments even if they have to increase more the expensive external financing. Such forces will weaken the link between the investment and cash flow for the small companies.

Another explanation is that the agency problems may be more pronounced for the majority of large companies because of the dispersion of capital ownership. The managers in these companies face less to the market discipline and may tend to increase the size of the firm whenever the internal funds are available.

Since Kadapakkam and al (1998) concluded that the small companies have a sensitivity to cash flow less than for those large companies, it is evident for them that the small companies in developing economies may depend more on external financing (may be the bank).

In a continental Europe context (Germany), Audretsch (2002) ${ }^{22}$ introduces the firm size and the institutional specificity to analyze the relationship between liquidity and investment. The results show that medium-sized companies seem to be, financially, more constrained than the smaller or the larger companies.

\section{3 - The effect of liquidity:}

The following table will summarize these results:

Table 5: Linear regression of the effect of liquid assets on the Cash Flow Investment sensitivity

\begin{tabular}{|c|c|c|c|}
\hline VARIABLES & $\begin{array}{l}\text { COEFFICIE } \\
\text { NTS }\end{array}$ & $\begin{array}{l}\text { T for } \\
\text { H0 :Parameter }= \\
\text { O }\end{array}$ & $\underset{\mid}{\operatorname{Prob}>\mid T}$ \\
\hline Constant & $\begin{array}{l}14.51383 \\
(0.623402)\end{array}$ & $23.28168^{*}$ & 0.0000 \\
\hline $\mathrm{CF}$ & $\begin{array}{l}-0.202008 \\
(0.029937)\end{array}$ & $-6.747810^{*}$ & 0.0000 \\
\hline CS & 0.286930 & $6.747925^{*}$ & 0.0000 \\
\hline
\end{tabular}

www.nber.org

21- Kadapakkam, P.R., Kumar, P.C. and Riddick, L.A, (1998), "The impact of cash flows and firm size on investment: The international evidence", Journal of Banking and Finance, vol.22

22- Ettaoufik, F (2004), « contraintes de liquidité, investissement et propriété : cas des PME belges de la haute technologie », www.solvay.edu 


\begin{tabular}{|l|l|l|l|}
\hline & $(0.042521)$ & & \\
\hline LA & $\begin{array}{l}-1.615607 \\
(0.060463)\end{array}$ & $-26.72048^{*}$ & 0.0000 \\
\hline DW & 2.771 & - & \\
\hline $\mathrm{R}^{2}$ & $89.02 \%$ & - & - \\
\hline $\mathrm{R}^{2}$ adjusted & $87.19 \%$ & - & - \\
\hline
\end{tabular}

* Significant at the $1 \%$ level.

The values between parentheses are the standard errors.

We notice that the liquidity expressed by the two explanatory variables, CS and LA, has a statistically significant effect on the of cash flow investment sensitivity, but we cannot give a final result concerning the sign of this effect, since the CS has a positive effect, while the LA has a negative effect.

We can notice that the CS reacts positively on this sensitivity. Greater will be the CS, the greater will be the relationship between the investment and the cash flow, that is to say, if the firm has an important cash stock, the cash flow will be substituted by the cash stock to finance its investment.

Concerning the LA, it has a negative impact. This result is the same as proved by Fazzari and Petersen (1993). For them, they incorporate into their basic model various sources of funds (especially working capital) and test the interaction between the investment and these new sources of financing. They noticed a negative relationship, especially, between the investment and the working capital.

The working capital allows appreciating the financial structure of a firm. It is a measure of the liquidity. It reflects a comparison between the assets liquidity and the liabilities.

So, we can say that the financial health of French companies is not good since the situation of their cash is not good (negative LA).

\section{Conclusion:}

The investment-cash flow sensitivity has been the main point of several empirical studies, whereof the majority has proved the existence of such relationship, both, significant and positive between the investment and the cash flow, but the unanimity was not made on the explanation of this positive relationship.

For our own results, we noticed that the $\mathrm{MC}$, as a measure of the firm size, has a positive and significant effect on this relationship (investment-cash flow).Also, the DLMT have a negative effect on the investment-cash flow sensitivity.

Finally, the impact of the liquid assets on the cash flow investment sensitivity is not clear. Since the effect of CS is positive while the effect of LA is negative. 


\section{Ml Macrothink}

International Journal of Accounting and Financial Reporting

ISSN 2162-3082

2012, Vol. 2, No. 2

\section{References}

1. Allayannis, G. and Mozumdar, A, (2000), « Cash flow, investment, and hedging », www.ssrn.com

2. Artola, C., Esteban A., Hernando I., Ortega M., Sauvé A., Sastre T., Tiomo T. et Tournier A. (2002), «Investissement et contraintes financières en France et en Espagne: Etude économétrique sur données d'entreprises manufacturières ", Bulletin de la Banque de France, $N^{\circ} 106$, p.73-84

3. Barnea, A. , Haugen, R. A. and Senbet, L. W. (1980), “ A rationale for debt maturity structure and call provisions in the agency theoric framework", The Journal of Finance, Vol. 37, N5, p.1223-1234.

4. Baude, J. (2005), «L'impact des chocs boursiers sur le crédit en France depuis le milieu des années quatre-vingt-dix », www.banque-france.fr

5. Bernstein L. (1975), «In Defense of Fundamental Investment Analysis», Financial Analysis Journal, Jan-Feb, p. 57-61

6. Bigout-Lare N. (1995), «Décision d'investissement et décentralisation du processus de prise de décision dans l'entreprise togolaise ", www .google .com

7. Butler, R., Davies, L., Pike, R. and Sharp, J. (2007), "Strategic investment decision-making: complexities, politics and processes", Journal of Management Studies, vol.28, Issue4, p.395-415

8. Chan L. K. C., Lakonishok J. and Sougiannis T. (1999), "The stock market valuation of research and development expenditures", www.ssrn.com

9. Childs, P.D., Mauer, D.C. and Ott, S.T., (2005), "Interactions of corporate financing and investment decisions: The effects of agency conflicts", Journal of Financial Economics, vol.76, Issue.1, p.20-27

10. Chirinko, R. and Schaller, H (1995), «Why does liquidity matter in investment equations? », Journal of Money, Credit and Banking, vol.27, N², p.527-548

11. Cohen, W.M. and Klepper, S, (1996), "A reprise of size and R\&D”, The Economic Journal, vol.106, N43, p.925-951

12. Connolly, R.A and Hirschey,M (2005), «Firm size and the effect of R\&D on Tobin's q », R\&D Mangement, 35,2, p.217-223

13. Devereux.M and Schiantarelli.F (1989), «Investment, financial factors and cash flow : Evidence from UK panel data », www.nber.org

14. Ding Y. Et Stolowy H. (2003), "“Capitalisation" des frais de RD en France : déterminants et pertinence », www.google.com

15. Estrada, A. and Valles, J, (1998), «Investment and financial structure in Spanish manufacturing firms », Investigaciones Economicas, vol.XXII (3), p.337-359

16. Ettaoufik, F (2004), «contraintes de liquidité, investissement et propriété : cas des PME belges de la haute technologie », www.solvay.edu

17. Fagiolo, G. and Luzzi, A, (2006), «Do liquidity constraints matter in explaining firm size and growth? Some evidence from the Italian manufacturing industry", 
Industrial and Corporate Change, vol.15, $\mathrm{N}^{\circ} 1, \mathrm{p} .1-39$

18. Fazzari.S-M, Hubbard.R-G and Petersen.B-C (1997), "Financing constraints and corporate investment: response to Kaplan and Zingales", www.nber.org

19. Fishman, A. and Rob, R, (1999), «The size of firms and R\&D investment », International Economic Review, vol.40, $\mathrm{N}^{\circ} 4$, p.915-931.

20. Galeotti M., Schiantarelle F. and Jaramillo F. (1994), «Investment decisions and the role of debt, liquid assets and cash flow: evidence from Italian panel data", Applied Financial Economics, Vol.4, p.121-132

21. Ghosal, V. and Loungani, P, (1996), «Firm size and the impact of profit-margin uncertainty on investment : Do financing constraints play a role ?», International Finance Discussion Papers, $\mathrm{N}^{\circ} 55$

22. Hennessy, C.A, (2004), «Tobin's Q, debt overhang and investment», The Journal of Finance, vol.LIX, $N^{\circ} 4$, p.1717-1742

23. Huang, Z (2005), «Financial constraints and Investment - Cash-flow sensitivities », www.ssrn.com.

24. Kadapakkam P. R., Kumar P. C. and Riddick L. A. (1998), "The impact of cash flows and firm size on investment: The international evidence", Journal of Banking and Finance, Vol.22, p.293-320

25. Kaplan, S-N and Zingales.L, (1997), "Do financing constraints explain why investment is correlated with cash flow?", www.nber.org

26. Kaplan, S-N and Zingales.L, (2000), “ Investment - cash flow sensitivities are not valid measures of financing constraints", www.nber.org

27. Kergueris,J (2002), «Les déterminants de l'investissement», Rapport d'information du Sénat N³5 (2002-2003), www.senat.fr

28. Kremp, E. et Stöss, E. (2001), «L'endettement des entreprises industrielles françaises et allemandes: des évaluations distinctes malgré des déterminants proches », Economie et Statistique, N³41, 1/2, p.135-171

29. Lamont O. (1997), "Cash flow and investment: Evidence from Internal Capital Markets”, The Journal of Finance, Vol. LII, N¹, March 1997, p.83-109

30. Liu, Q. and Qi, R, (2002), «Information production, cash flow and corporate investment », www.ssrn.com

31. McGuire, P.M, (2003), « Bank ties and bond market access : evidence on investment - cash flow sensitivity in Japan", www.nber.org

32. Meschi P-X. \& Metais E. (2002), « investissements Français aux Etats-Unis, stratégies de croissance et réactions du marché », Finance-Contrôle-Stratégie, Vol.5, $\mathrm{n}^{\circ} 1, \mathrm{p}$ 129-165.

33. Miguel A. and Pindado J. (2001), "Determinants of capital structure: new evidence from Spanish panel data", Journal of Corporate Finance, Vol 7

34. Moyen, N, (2002), «Investment - cash flow sensitivities : constrained versus unconstrained firms », www.ssrn.com 
35. Myers S.C. and Majluf N.S. (1984), «Corporate financing and investment décisions when firms have informations that investors do not have », Journal of Financial Economic, vol. 13, p.187-221

36. Nam, C.W. and Radulescu, D.M, (2004), « Does debt maturity matter for investment decisions", www.ssrn.com

37. Savignac, F, (2006), «L'impact des contraintes financières sur l'innovation : une étude empirique sur données françaises », www.google.com

38. Worthington, A.C and West, T. (2001), «The usefulness of economic value added (EVA) and its components in the Australian context», Accounting, Accountability and Performance 7(1) 2001,pp. 73-90. 